\title{
Hygrophorus exiguus, a new species in subgenus Colorati section Olivaceoumbrini, subsection Tephroleuci
}

\author{
ELLEN LARSSON, EMANUELE CAMPO and MATTEO CARBONE
}

\begin{abstract}
LARSSON, E., CAMPO, E. \& CARBONE, M. 2014: Hygrophorus exiguus, a new species in subgenus Colorati section Olivaceoumbrini, subsection Tephroleuci - Karstenia 54: 41-48. HELSINKI. ISSN 0453-3402.

Hygrophorus exiguus, a new species, is described and illustrated. In Fennoscandia this species is associated with rather moist old growth mixed Picea abies forests of the Vaccinium myrtillus type. In Southern Europe it is associated with mixed P. abies and Abies alba forests on higher elevations. It seems to be growing solitarily deep in mosses, often among Tricholoma inamoenum. The species is likely to be rare but may be overlooked, has a broad distribution in Europe and is found in Finland, Sweden, Italy and France. It is closely related to $H$. agathosmus, $H$. hyacinthinus and $H$. odoratus, but can be segregated from these by its small fruiting bodies, with a cap diameter rarely exceeding $20-25 \mathrm{~mm}$ and the pinkish tint of the lamellae. Like H. agathosmus, it has the odour of marzipan or bitter almonds but less pronounced.
\end{abstract}

Key words: Agaricales, Hygrophoraceae, Hygrophorus exiguus, Tricholoma inamoenum, phylogenetic systematics, taxonomy, ITS

Ellen Larsson, University of Gothenburg, Biological and Environmental Sciences, Box 461,40530 Göteborg, Sweden; e-mail: ellen.larsson@bioenv.gu.se

Emanuele Campo, Via dei Gelsi 8, 33077 Sacile (PN), Italy; e-mail: ecampo@alice.it

Matteo Carbone, Via Don Luigi Sturzo 173, 16148 Genova, Italy; e-mail: matteocarb@, hotmail.com

\section{Introduction}

Species in the genus Hygrophorus Fr. form ectomycorrhizal associations with tree roots and are mostly restricted to the temperate regions in the Northern hemisphere (Tedersoo et al. 2010). The genus is considered well known and currently we recognize about 36 species in Fennoscandia (Larsson et al. 2011) and about 50 species in Europe (Candusso 1997). Most species are likely to be host specialists, a character that offer support in species identification of morphologically similar species (Larsson \& Jacobsson 2004, 2007).

The family Hygrophoraceae Lotsy has recently been revised using new knowledge, by integrated molecular phylogenetic and morphological analyses, and by taking pigment chemistry and ecology into account. A coherent classification for the family, including Hygrophorus, was proposed (Lodge et al. 2014). In the new classification, the subgenus Colorati (Bataille) E. Larss. is divided into three sections: Olivaceoumbrini (Bataille) Konrad \& Maubl., Pudorini (Bataille) Konrad \& Maubl., and Aurei (Bataille) E. Larss. In addition, the section Olivaceoumbrini is divided into subsections Olivaceoumbrini (Bataille) Singer and Tephroleuci (Bataille) Singer.

For some years a small Hygrophorus species 
found in old growth Picea abies forest has caught our attention. It may at first resemble fruiting bodies of $H$. agathosmus (Fr.) Fr. or H. hyacinthinus Quél., but the habit is more mycenoid to omphaloid. The smell is similar but less pronounced. The species may be rather rare in Fennoscandia, connected to the old growth Picea forest, or overlooked because of its small habit and scattered occurrence of specimens. The species has also been encountered in Southern Europe, and then the name $H$. odoratus A. H. Sm. \& Hesler has been applied (Papetti 1996, Bidaud 2007). In this paper we describe the new species $H$. exiguus, a species that is shown to belong in subsection Tephroleuci, based on morphology and molecular data.

\section{Material and methods}

Macro-morphological characters were noted from fresh fruiting bodies. Dried fruiting bodies were used for microscopic examinations. Spore dimensions and micromorphological characters were studied and measured using Axioscope 2 (Zeiss) and AxioVision 4 software (http:// microscopy.zeiss.com) or Olympus CX41. Samples were rehydrated using 3\% $\mathrm{NH} 4 \mathrm{OH}$ and then observed in anionic Congo red. To test the nature and colours of the pigments, a solution of $\mathrm{H}_{2 \mathrm{O}}$ and $\mathrm{NaCl}$ was used. For each specimen at least 30 spores and 10 basidia were measured. For the drawings, the measurements of the pileipellis, stipitipellis and gill trama include the holotype and paratype of the $H y$ grophorus exiguus and $H$. odoratus, respectively. The averages of basidia and spores are given in italics.

Sequences of the complete ITS region were generated for two specimens of Hygrophorus odoratus (Herbarium $\mathrm{MICH})$ and three specimens previously determined to $H$. cf. odoratus or Hygrophorus sp.. In addition, specimens of $H$. agathosmus and $H$. hyacinthinus were included for comparison. Hygrophorus pustulatus was selected as the outgroup. DNA extractions and PCR reactions were performed as described in Larsson \& Jacobsson (2004). Sequences of the ITS region of the isotype of $H$. odoratus (TENN023658, HQ185705) and H. hyacinthinus (GB0124675, HM143012) were retrieved from GenBank. Sequences were edited and assembled using Sequencher 5.1 (Gene Codes, Ann Arbor. Michigan). Sequences were aligned automatically using the L-INS-i strategy as implemented in MAFFT v. 7.017 (Katoh \& Standley 2013). The alignment was adjusted manually using the data editor in PAUP* (Swofford 2003). Heuristic searches for most parsimonious trees were performed using PAUP*. All transformations were considered unordered and equally weighted. Variable regions with ambiguous alignment were excluded and gaps were treated as missing data. Heuristic searches with 1000 random-addition sequence replicates and TBR branch swapping were performed. Relative robustness of clades was assessed by the bootstrap method using 1000 heuristic search replicates with 100 random taxon addition sequence replicates and TBR swapping.

\section{Results}

Ten ITS sequences were newly generated for the study. These have been deposited in GenBank (accession no. KJ720991-KJ720200). The aligned complete dataset consisted of 12 taxa and 656 characters. After the exclusion of ambiguous regions, 472 characters remained for the analysis. Of these, 413 were constant, 2 were variable but parsimony uninformative, and 57 were parsimony informative. The maximum parsimony analysis yielded a single most parsimonious tree (length $=76$ steps, $C I=0.9605$, and $\mathrm{RI}=0.9766$ ). The most parsimonious tree is presented as a phylogram (Fig. 1).The bootstrap analysis recovered four strongly supported clades, corresponding to Hygrophorus agathosmus $(100 \%), H$. hyacinthinus $(100 \%), H$. odoratus $(100 \%)$ and the herein new described species $H$. exiguus (99\%) (Fig. 1.)

\section{Taxonomy}

\section{Hygrophorus exiguus E. Larss., E. Campo \& M. Carbone, sp. nova - Figs. 2-4}

\section{MycoBank no.: MB 808838}

Differs macroscopically from Hygrophorus agathosmus, $H$. hyacinthinus and $H$. odoratus by having distinctly smaller fruiting bodies and a pink tint of the lamellae. Fruiting bodies grow solitarily or scattered, and are not fasciculate nor in fairy rings. The odour is faint of marzipan but not as strong as in H. agathosmus.. Differs in the ITS sequence data from $H$. agathosmus, $H$. hyacinthinus and $H$. odoratus.

Typus: Finland. Koillismaa. Kuusamo, Oulanka National Park, Ampumavaara. In moist Picea abies dominated mixed forest, growing among fruiting bodies of Tricholoma inamoenum, 18.VIII.2009 Calledda, Pini, Boerio \& Carbone (TUR-A 190791 - holotype; GB - isotype, GenBank Acc. No. KJ720198).

Etymology: exiguus refers to the small habit of the fruiting bodies.

Pileus $8-20(-25) \mathrm{mm}$ in diam, campanulate to convex, usually with a broad and blunt umbo, margin long remaining incurved, becoming more 


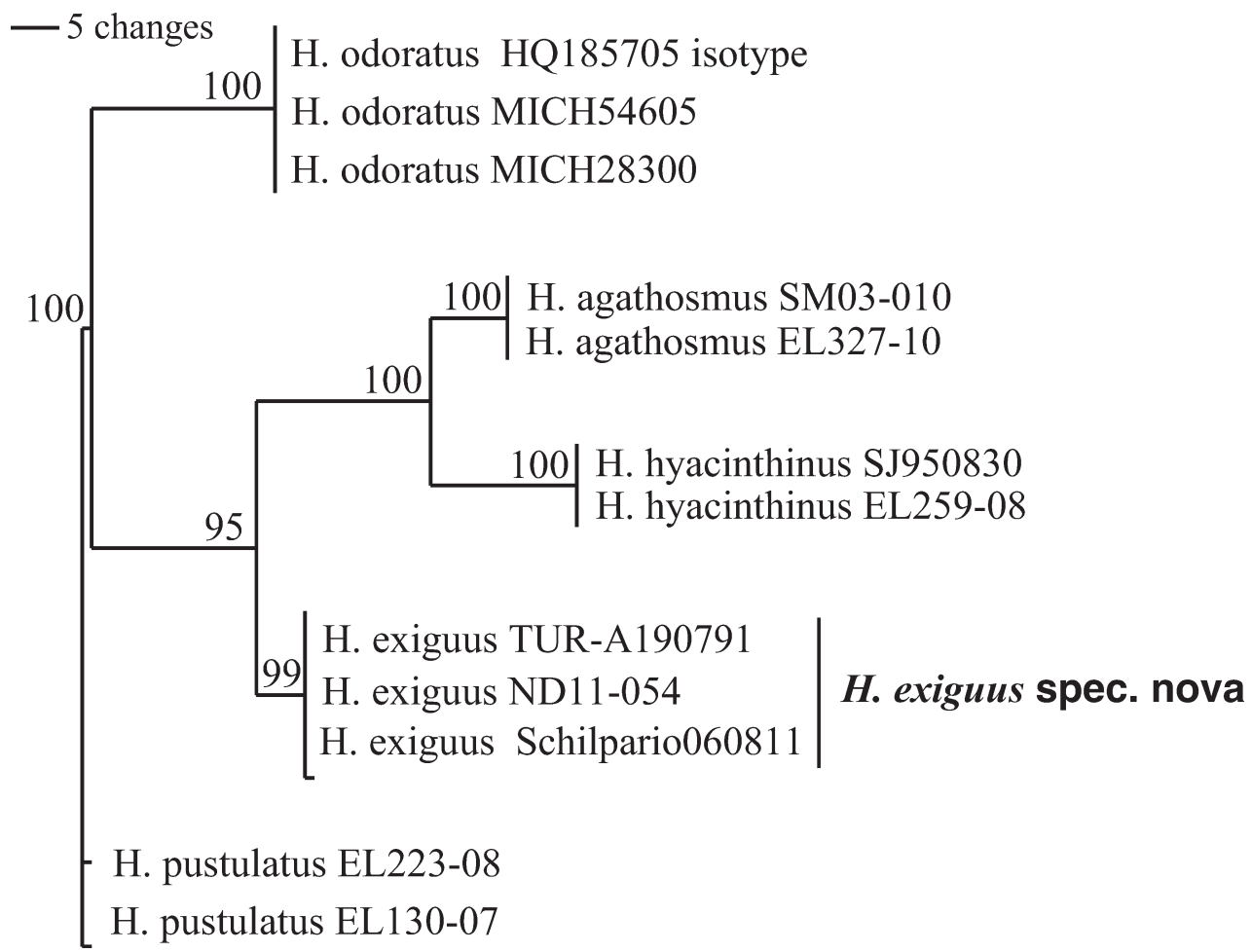

Fig. 1. The most parsimonious tree from the maximum parsimony analysis, presented as a phylogram, showing the position of Hygrophorus exiguus in relation to the other species in subsection Tephroleuci. Bootstrap values are indicated on the branches.

plane with a low obtuse umbo, pale grey to grey with a beige tone, viscid, context white. Margin finely fibrillose to pubescent, somewhat plicate when unexpanded. Lamellae adnate to decurrent, $\mathrm{L}=25-38$, distant, broad, a few furcate, first snow white, later with a pale cream to pinkish tint. Stipe 20-40(-50) mm long, 3-4(-6) mm thick, equal, white, dry, glabrous at lower parts, upper half fibrillose and with small warts. Taste none, odour faintly of marzipan, similar to $H$. agathosmus. Spores ovoid to broadly ellipsoid, smooth, hyaline, 9.2-10.0-11.4 × 5.3-5.9-6.8 $\mu \mathrm{m}$, mean $\mathrm{Q}=$ $1.7(\mathrm{n}=90)$. Basidia 44-53-68 × 7.3-8.4-10.3 $\mu \mathrm{m}$, narrowly clavate with sterigmata up to 8 $\mu \mathrm{m}$, mainly 4-spored, few 2-spored. Clamp-connections present. Gill trama divergent, consisting of interwoven inflated parallel hyphae $8-20 \mu \mathrm{m}$ broad. Pileipellis gelatinous, with tangled narrow hyphae $2-5 \mu \mathrm{m}$, an ixotrichoderm 150-200 $\mu \mathrm{m}$, epi-membranaceous yellow pigment is present. Stipitipellis a thin cutis made up of more or less parallel hyphae 3-6 $\mu \mathrm{m}$ broad, fibrils made up of erect hyphae with large clamp connections and slightly enlarged terminals, club-shaped up to 8-10 $\mu \mathrm{m}$ broad, sometimes bending.

Additional specimens studied: ITALY. Lombardia. Province of Bergamo, Schilpario, 1200 m a.s.l., in mossy mixed Picea abies and Abies alba forest, growing among fruiting bodies of Tricholoma inamoenum, 6.VIII.2011 Mantovani \& Calledda (GB, TUR-A, GenBank Acc. No. KJ720200). SWEDEN. Dalsland. Skållerud. In old growth forest under Picea abies, growing among fruiting bodies of $T$. inamoenum, 23.IX.2014 Jacobsson 14-046 (GB). Västergötland. Skepplanda, Slereboåns NR, in old moist $P i$ cea abies dominated forest, growing among fruit- 
ing bodies of T. inamoenum, 21.IX.2014 Larsson 189-14 and 190-14 (GB); Horla, Yxnås NR, coniferous forest, under Picea abies, growing among fruiting bodies of $T$. inamoenum, 28.IX.2014 Larsson 198-14 (GB). Västerbotten. Vindeln, Kluddbrännan, in old growth forest with Picea $a b$ ies, Pinus sylvestris, and Betula pendula, in deep mosses with Vaccinium sp., 26.VIII.2011 Dam 11054 (L, GB, GenBank Acc. No. KJ720199).

\section{Specimens studied for comparison:}

Hygrophorus agathosmus: FINLAND. EteläHäme. Lammi, 2.IX.2000 Larsson 2-00 (GB). NORWAY. Akershus. Nesodden, Torvet, Sörby S, 11.IX.2010 Larsson 304-10 (GB). Nord-Tröndelag. Steinkjer, Skrattåsen, 5.IX.2009 Larsson 179-09 (GB). SWEDEN. Gotland. Ardre, Ollajvs NR. 27.IX.2010 Larsson 327-10 (GB). Västergötland. Skepplanda, Slereboåns NR, 13.X.2011. Larsson 355-11 (GB); Medelplana, Eriksberg, 20.VII.2004 Larsson 12-04 (GB). Dalsland. Skållerud, Håverud, 17.IX.2011 Larsson 249-11 (GB). Närke. Axberg, Kvinnerstatorp, 10.IX.2008 Larsson 110-08 (GB). Medelpad. Sättna, 2-3 km W of Västmansjö, 28.VIII.2003 Muskos 03-10 (GB). Jämtland, Hammerdal, $8 \mathrm{~km} \mathrm{~N}$, 23.VIII.2012 Larsson 126-12 (GB). Lule Lappmark. Jokkmokk, Rimakåbbå-Lattnjåive, 30.VIII.2011 Larsson 142-11 (GB).

Hygrophorus hyacinthinus: SLOVAKIA. Banskobystricky Kraj. Muránska Planina National Park, Murán, Vel'ka Lúka, Sedlo Javorinko, 10.X.2008 Larsson 259-08 (GB). SWEDEN. Gotland, Ardre, Ollajvs NR. 27.IX.2010 Larsson 326-10 (GB), 30.IX.2010 Larsson 394-10 (GB); Gerum, Sandarve kulle, 28.IX.2011 Larsson 309-11 (GB). Medelpad. Alnön, N. Grönviken, 30.VIII.1995 Muskos (GB).

Hygrophorus odoratus: USA. Oregon. Paradise Park, Mt. Hood, Clackamas Co., 20.X.1947 Smith 28387 (holotype, MICH). Mile Bridge, Mt. Hood Nat. Forest, 26.X.1947 Smith 28300 (paratype, MICH). Idaho. Granite Creek, Nordman, Bonner Co., under hemlock, 11.X.1956 Smith 54516 (MICH), 12.X.1956 Smith 54581 (MICH), 13.X.1956 Smith 54605 (MICH), 15.X.1956 Smith 54781 (MICH). 13.X.1956 Smith 23686 (TENN).
Priest Lake, Bonner Co., under hemlock and pine, 17.X.1956 Smith 54945 (MICH), 18.X.1956 Smith 54997 (MICH), 21.X.1956 Smith 55187 (MICH). Priest Lake, Bonner Co., under hemlock, 20.X.1956 Hesler 55136 (MICH).

\section{Discussion, ecology and distribution}

In Fennoscandia Hygrophorus exiguus seems to be a species associated with fairly moist old growth mixed Picea abies forest of the Vaccinium myrtillus type. Further south in Europe it grows in moist mixed forests with Picea abies and Abies alba on higher elevations. It is found growing solitarily deep in mosses, often in the same place and among Tricholoma inamoenum (Fr.: Fr.) Gillet. The species may be rare as the number of known collections of it in herbaria is small, but it may also be overlooked because of its small habit and resemblance to small specimens of $H$. agathos$m u s$. The trend that it is found together with $T$. inamoenum may indicate that the two species have the same ecological preferences and are fruiting at about the same time. This can facilitate future searches for new localities of $H$. exiguus.

Hygrophorus exiguus has a rather wide distribution in Europe and is known from Finland, Sweden, France and Italy. The first documentation of the species was likely that reported by $\mathrm{Pa}-$ petti (1997) from Italy. He determined and named his specimens as $H$. odoratus. Another specimen was reported by Bidaud (2007) from France, also under the name $H$. odoratus. However, most reports of the species $H$. odoratus from Europe are likely not to represent $H$. exiguus. Most of these collections are instead likely to be determined as other species in Hygrophorus. The occurrence of $H$. odoratus has been reported by several authors in the literature from Europe (eg. Bon 1990, Candusso 1997). So far there is no species report of $H$. odoratus confirmed with ITS sequence data, at least not that we know of, and blast searches in

Fig. 2. Fruiting bodies of the holotype of Hygrophorus exiguus. - Photo: M. Carbone.

Fig. 3. Fruiting bodies of Hygrophorus exiguus growing in a forest with Picea abies and Abies alba in Italy, Lombardia, Schilpario. Collection M. Mantovani \& F. Calledda 6.VII.2011. - Photo: F. Calledda. 

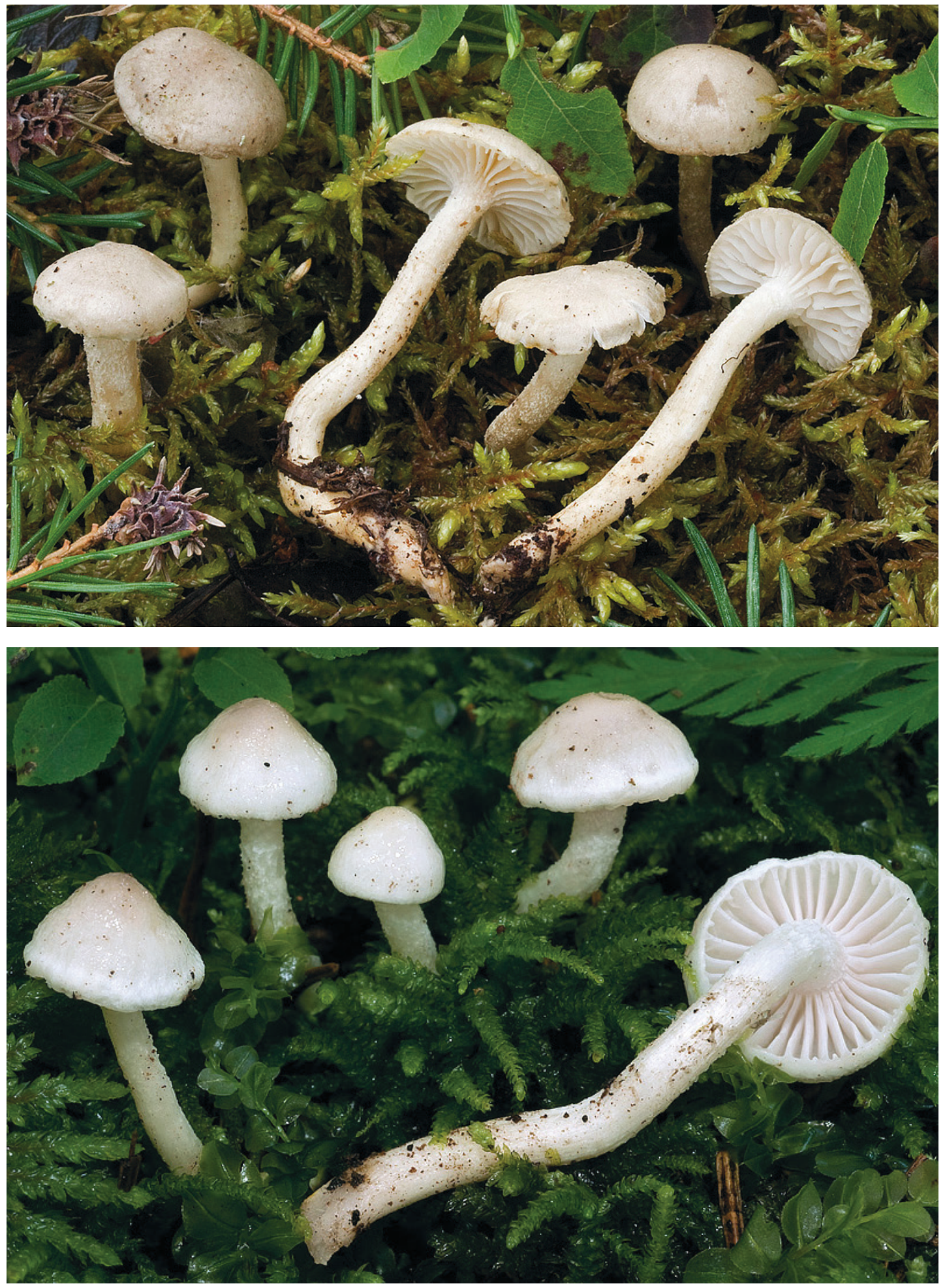


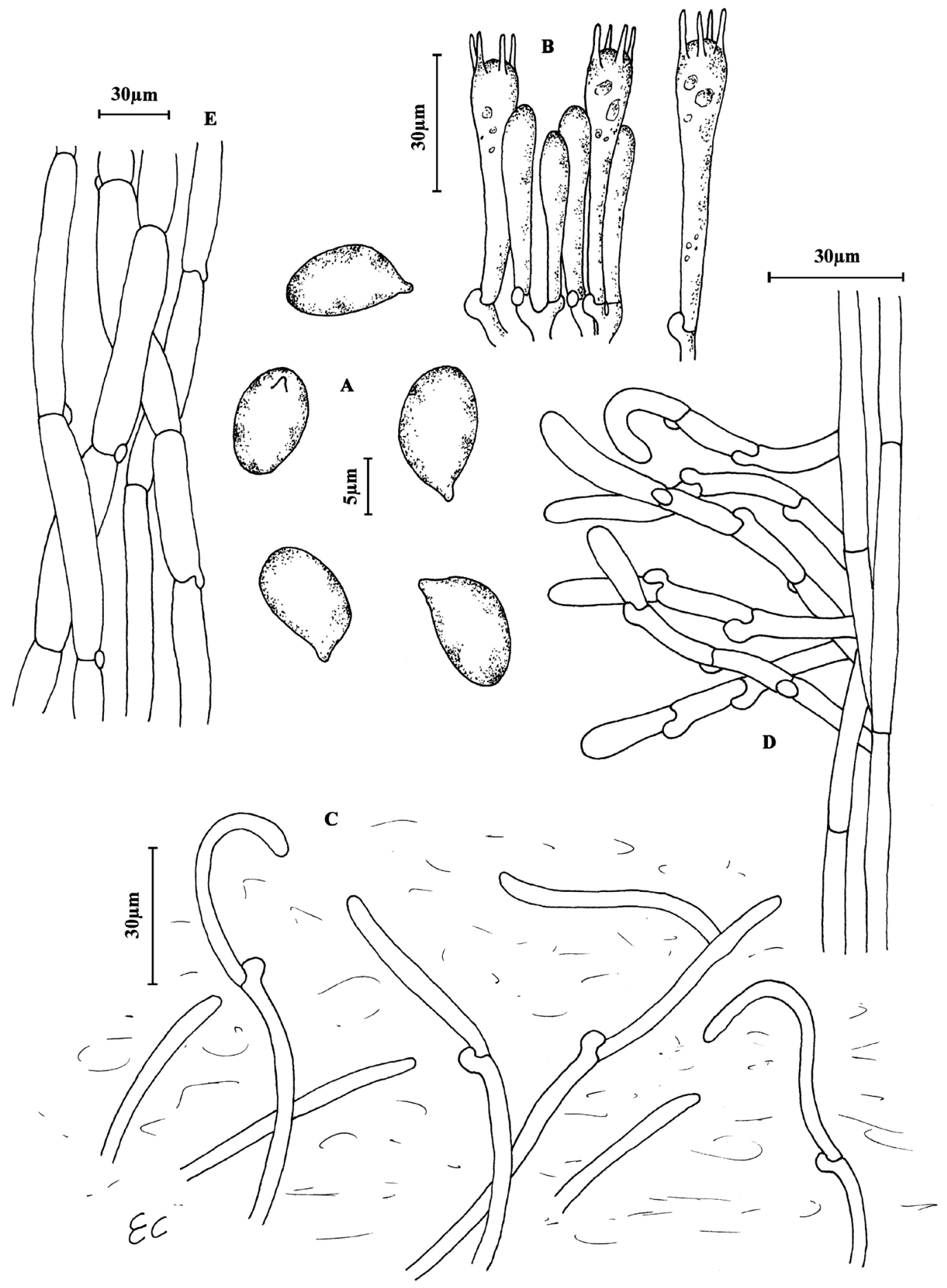

Fig. 4. Micromorphological characters of the holotype of Hygrophorus exiguus. $\mathrm{A}=$ spores, $\mathrm{B}=$ basidia, $\mathrm{C}=$ pileipellis, $\mathrm{D}=$ stipitipellis, $\mathrm{E}=$ gill trama. - Drawing: E. Campo. 


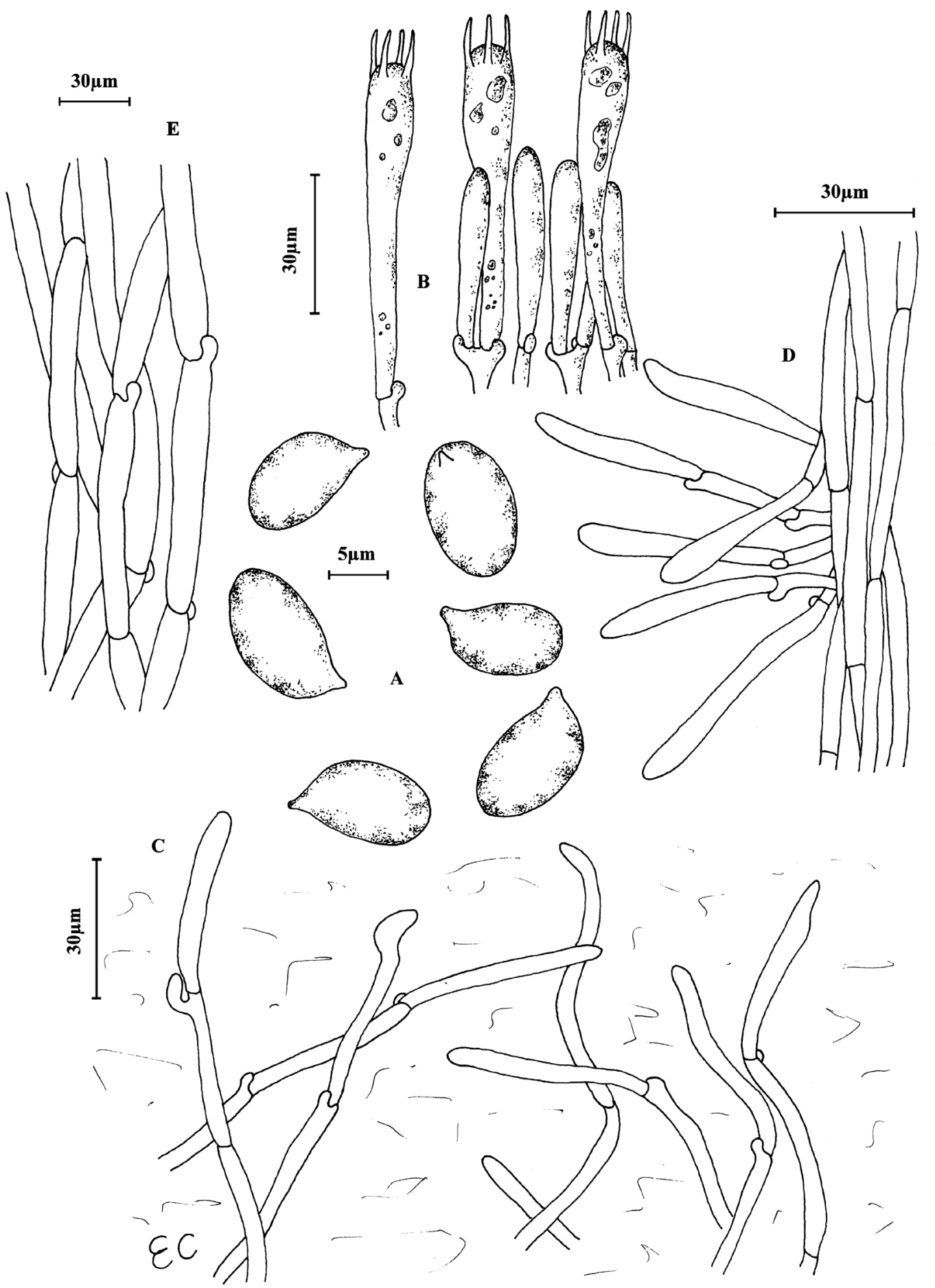

Fig. 5. Micromorphological characters of the holotype of Hygrophorus odoratus (A.H. Smith 28387). $\mathrm{A}=$ spores, $\mathrm{B}=$ basidia, $\mathrm{C}=$ pileipellis, $\mathrm{D}=$ stipitipellis, $\mathrm{E}=$ gill trama. - Drawing: $\mathrm{E}$. Campo. 
GenBank give no match to European sequences. In North America the species grows associated to Tsuga sp. and Pinus contorta Douglas ex Loudon. In this study a revision of the morphology of $H$. odoratus type material was done and detailed measurements of 10 collections determined by Smith were undertaken (Fig. 5). The spore measurements here, $9.0-11.5-12.0 \times 6.0-7.0-7.5 \mu \mathrm{m}$, (mean $\mathrm{Q}=1.6, \mathrm{n}=300$ ), were found to be somewhat smaller than those given by Hesler \& Smith (1963), but still slightly larger than the measurements for $H$. exiguus 9.2-10.0-11.4 × 5.3-5.9-6.8 $\mu \mathrm{m}($ mean $\mathrm{Q}=1.7, \mathrm{n}=90)$. Otherwise the micromorphology of the two species is rather similar (Figs. 4 and 5). The four species in subsection Tephroleuci dealt with in this study are all very similar in micro-morphology and with just small differences in spore measurements. Both $H$. agathosmus 8.4-9.5-11.0 × 4.8-5.5-6.4 $\mu \mathrm{m}$ (mean $\mathrm{Q}=1.7, \mathrm{n}=90)$ and $H$. hyacinthinus 8.6-10.0-11.3 $\times$ 4.8-5.3-6.2 $\mu \mathrm{m}$ (mean $\mathrm{Q}=1.9, \mathrm{n}=90$ ) have slightly smaller spores than $H$. exiguus.

Specimens of $H$. agathosmus, $H$. hyacinthinus and $H$. odoratus are all considerable larger in size than the here described new species, $H$. exiguus. The small cap size, rarely exceeding $20-25 \mathrm{~mm}$ in diam and the more mycenoid/omphaloid habitus of younger fruiting bodies should therefore be good characters for the identification and segregation from the other species. Hygrophorus hyacinthinus is a rare species and in Northern Europe only found in old growth Picea forest on rich calcareous soil. It is classified as endangered (EN) in the Swedish red list of species (Gärdenfors 2010). Hygrophorus agathosmus is a common species and occurs in the same type of forest as $H$. exigu$u s$, at least in Fennoscandia, but it often favours grassy sites in human-influenced habitats such as planted forests, parks and road-sides.

Acknowledgements: We thank the Swedish Taxonomy Initiative, ArtDatabanken SLU Uppsala (EL). The curators Patricia Rogers (MICH), Giovanni Robich (MCVE) and Ron Petersen (TENN) for arranging loans of H. odoratus material, Nico Dam for generously sharing his specimen from Kluddbrännan. Stig Jacobsson and Jukka Vauras are thanked for suggestions that improved the manuscript and Bernard Pfeil for improving the language.

\section{References}

Bidaud, A. 2007: Jounée des espèces rares ou intéressantes 2005 - 3 parte. - Bull. Mycol. Bot. Dauphiné-savoie 184: 33-34.

Bon, M. 1990: Flore Mycologique d'Europe. 1. Hygrophores. Hygrophoraceae Lotsy. - Documents Mycologiques mémoire hors série 1.

Candusso, M. 1997: Hygrophorus s. 1. Fungi Europei Vol 6. Libreria Basso, Alassio.

Gärdenfors, U. (ed.) 2010: The 2010 Red List of species. Artdatabanken, SLU. Uppsala (wwwartdatabanken.slu. se/rodlista).

Hesler, L.R. \& Smith, A.H. 1963: North American species of Hygrophorus. Knoxville.

Jacobsson, S. \& Larsson, E. 2007: Hygrophorus penarioides, a new species identified using morphology and ITS sequence data. - Mycotaxon 99: 337-343.

Katoh, K. \& Standley, D.M. 2013: MAFFT multiple sequence alignment software version 7 , improvements in performance and usability. Molecular Biology and Evolution. doi, 10.1093/molbev/mst010.

Larsson, E. \& Jacobsson, S. 2004: Controversy over Hygrophorus cossus settled using ITS sequence data from 200 year-old type material. - Mycological Research 113: 1154-1171.

Larsson, E., Jacobsson, S. \& Stridvall, A. 2011: Släktet Hygrophorus, Skogsvaxskivlingar i Sverige. En fältguide till SMF:s svampväkteri. - Mykologiska Publikationer 3: 1-56, ISSN 1654-546x

Lodge, D.J., Padamsee, M., Matheny, P.B., Aime, M.C., Cantrell, S.A., Boertmann, D., Kovalenko, A., Vizzini, A., Dentinger, B.T.M., Kirk, P.M., Ainsworth, A.M., Moncalvo, J.-M., Vilgalys, R., Larsson, E., Lücking, R., Griffith, G.W., Smith, M.E., Norvell, L.L., Desjardin, D.E., Redhead, S.A., Ovrebo, C.L., Lickey, E.B., Ercole, E., Hughe, K.W., Courtecuisse, R., Young, A., Binder, M., Minnis, A.M., Lindner, D.L., Ortiz-Santana, B., Haight, J., Læssøe, T., Baroni, T.J., Geml, J. \& Hattori, T. 2014: Molecular phylogeny, morphology, pigment chemistry and ecology in Hygrophoraceae (Agaricales). - Fungal Diversity 64: 1-99.

Papetti, C. 1997 Hygrophorus odoratus A. H. Sm. \& Hesler. - Bolletino del Circolo Micologico G. Carini 32: inserto a colori.

Swofford, D.L. 2003: PAUP*. Phylogenetic Analysis Using Parsimony (* and Other Methods). Version 4. Sinauer Associates, Sunderland, MA.

Tedersoo, L., May, T. W. \& Smith, M. E. 2010: Ectomycorrhizal life style in fungi: global diversity, distribution, and evolution of phylogenetic lineages. - Mycorrhiza 20: $217-263$. 